\title{
Improving Attributes of Teacher Education: An Analysis
}

\author{
Dr. Amandeep \\ Associate Prof \\ Department of Evening Studies \\ Multi Disciplinary Research Centre Panjab University \\ Chandigarh, India \\ amandeep.deep78@gmail.com
}

\begin{abstract}
Teacher education has been a cause of serious concern. Despite several commission and committees the state of affairs in these schools and colleges of education remains pretty much the same as it used to be three or even four decades ago. The paper analyses the new practices, policies and procedures in the area of teacher education that affect the quality of teacher education and accordingly the education and the nation. The attempt here is to describe several innovations that have been introduced in this field for instance NCTE, continuing Education and its centres, correspondence Education, experiments, Technology, Microteaching, UGC Panel on Teacher Education and population Education etc. These methods are indicative that the role and responsibility of the teacher is vital for the individual personality and socio-scientific as well as socio-cultural progress of society and humanity.
\end{abstract}

Keywords- Education, Commission, Committees, Practices, Innovations, Pedagogy. 
Qualitative improvement in education depends on quality of teacher education because teacher has a crucial role in the development of the country and it is rightly said that the destiny of the county is formulated in its classrooms. New practices, policies and procedures in the area of teacher education affect the quality of teacher education and accordingly the education and the nation. Teacher educators have acted as if education is a purposeless activity with no relationship to the great problems of the time.( Edelfelt, 145).

Some of the current trends and innovations in teacher education are given hereunder.

\section{Inter-Disciplinary Approach}

India have taken the lead in making inter-disciplinary approach which is an integral part of the programme of teacher education. There can be no better plan for improving the quality of teacher education than by integrating content and methods, e.g., through theater-disciplinary approach.

\section{Internship in Teaching}

Internship in teaching includes practice teaching and wide variety of field experiences under the guidance of a competent supervisor. The learner tests his theoretical understanding acquired through pedagogy classes.

Its objectives are as follows:

(i) To develop functional understanding of educational psychology and methodology among interns. 
(ii) To develop skills in the planning of lessons and developing an ability of preparing instructional material and teaching aids.

(iii) To develop positive attitudes for continuous learning and keeping abreast with the latest of content and methodology.

(iv) To understand and practice the professional sincerity and professional ethics.

(v) To develop constructive and cooperative attitude towards students and the community.

The main purpose of the programme of practice teaching is to provide real experience prospective teachers and to initiate them in the skills of teaching the children. If the aim of education is to make people more alive, then the colleges should prepare men and women to develop same minds in sane bodies. (srivastava, 83).

\section{Community Living}

Another current trend in teacher education which can be noticed from the practices in abroad is to give some weightage to the programmes which have a training potential for community living.

The major aims of 'Community Living' programmes are personal and social effectiveness. Some essential features of the programme are:

(i) Group living by making the residence in the hostel compulsory.

(ii) Taking group projects such as cleanliness of premises, room and lecture theatres, etc.

(iii) Management of playing indoor and out-door games.

(iv) Organizing some entertainment and variety programmes. 
(v) Running the cooperative messes.

(vi) Arranging study groups for specified periods and evaluating the achievements.

\section{Orientation Course}

The objectives of such a course for the B.Ed. students are:

(i) To orient the incoming students to the nature, scope and significance of their respective training programme.

(ii) To orient them according to the needs and responsibilities of the Education Department.

(iii) To orient them according to the specific course choice available in their respective programmes.

(iv) To develop closeness and familiarity with their classmates and advisors.

This course is organized for a period of 4 to 6 days depending upon the needs of the students.

\section{Correspondence Course}

This is a new technique for in-service teachers. Correspondence course are being successfully done by different professional groups in several countries of the world. Experts who have visited U.S.A., U.S.S.R. and Australia have reported that correspondence courses are regarded in these countries as a normal vehicle of education in many areas.(Sharma, 291).

\section{Action Research}

(i) Seminars, discussions and workshop even though of short duration will help to improve the content knowledge of the student-teachers. 
(ii) Acquainting the trainees with the techniques of teaching and demonstration of skills an involving them in a series of rehearsals of teaching at the beginning does not seem to improve their skills of teaching more quickly than the usual practice. It could, however, be concluded from the findings of the self-evaluation test that favorable attitude could be created through such methods.

\section{Team Teaching}

Team teaching is also called cooperative teaching. It occurs when two or more teachers share in planning and conducting instruction that is offered to the same group of students. Teams vary in size from 2 elementary teachers who share the instruction offered to 40 or 50 students to teams made up of many as the teachers and over 200 students.

Anderson (1966) has listed seven characteristics of team teaching that represent contributions by various authors, and that may be considered as advantages:

(i) Specialization in teaching functions.

(ii) Flexible sub-grouping of pupils.

(iii) Flexible, efficient use of school resources.

(iv) Ease of using professional and non-professional as supplementary teachers.

(v) Wider range of resources and technologies used.

\section{Programmed Instruction}

Programmed instruction is a revolutionary device in the science of leaning, now-a-days, its use in the field of teacher education has also attained importance.

Advantages: The following are the main advantages: 
(i) Here the student remains active, and proceeds according to his own pace.

(ii) It makes optimum use of all the scientific principles of efficient.

(iii) Here learning becomes efficient, pleasant and permanent learning.

(iv) It may be adopted for home study and can save the teacher from devoting time to the correction of home work.

\section{Population Education as New Concept}

Population education is an absolutely new area and teachers know neither the content nor the way to teach it. They should be oriented to the new curriculum and trainees to use instructional material that is to be used in the classroom, and also to provide suitable learning experiences to pupils differing in age and maturity.

'Population Education' concept should be given to the teachers and develop the attitude to have the small family. It is very essential for the economic growth of the family and country. This feeling and attitude should be develop among the students in very beginning.

Thus concept of 'Population Education' should be given to the new generation so that they can realize his difficulties as well as... This is not content but feelings and attitudes should be developed by the teacher among the students. It needs that teacher should also trained for 'Population Education'.

The teacher preparation programme mainly involves the following steps:

(a) The development of population education curriculum for teacher.

(b) The development of techniques of teaching population education and instructional materials, and providing for programmes of pre-service training. 
(c) For teachers entering the profession and programmes of inservice training (for teachers already inservice).

\section{Objectives and Content Of The Teacher Education Programme}

The main objectives of teacher-education programme is to prepare teachers for effective functioning of schools. The population education concept is a part of theory content of national integration and international understanding. The content of population education to be included in teacher education programme depends upon the objective of the course.

The content of population education should be imparted to pupil teachers at cognitive as well as at affective level and behavioural level. The student-teacher should be sensitive about future growth of population and its danger for education and social and economic development. Research should be encouraged to explore certain specific features and characteristics of population education.

\section{National Council of Teacher Education}

The NCTE was set up by the Government $\mathrm{f}$ India on 21 May 1973, with a view to bringing about desired reforms in teacher education.

The NCTE had to (i) advise the Government of India on all matters concerning teacher education including pre-service and in-service training, evaluation of curricula for teacher education and periodical review of progress in revising curricula, (ii) advise state governments on any matter referred to the Council by them.

One of the roles of NCTE is to act as an accreditation agency which is very significant. 
The courses, syllabi and source material of teacher training courses at different levels have either been revised or developed by NCTE. These are (i) integrated two-year course in pre-school and primary teacher education, (ii) primary teacher education curriculum, (iii) B.Ed. (early childhood education) course, (iv) courses for studies for B.Ed. (elementary education) and M.Ed. (elementary education), (v) revised M.Ed. (secondary education programme).

\section{Continuing Education Centres}

Traditional methods of in-service training having been ineffective and also expensive, the NCERT started correspondence-cum-contact courses for secondary school teachers and primary teachers from January 1977. These courses are currently being run in all the four Regional Colleges of Education.

\section{Correspondence Education}

Correspondence education as a concept was developed to equip practicing persons to enquire fresh knowledge and skill without giving up their position. The history of correspondence education as such is fairly old. In the year 1840, Pitman sent instructions to his students in short-hand by postcard. A Frenchman Charles Toussaint founded a school for correspondence in Germany in 1856 in collaboration with Gustav Langerscheidt. This was the school for teaching languages through correspondence.

\section{Objectives:}

(i) To provide an efficient and less expensive method of educational instruction at a higher level in the context of the national development of India. 
(ii) To provide facilities to pursue higher education to all qualified and willing persons who had failed to join regular university courses due to personal or economic reasons; or because of their inability to get admission to a regular college.

At present two types of correspondence education courses are being offered by NCERT. These courses are run in all the four Regional Colleges of Education at Ajmer, Bhopal, Bhubaneswar and Mysore.

\section{Experiments in Teacher Education}

With a view to encouraging experimentation by practicing teachers of secondary schools on the problem which they face everyday in the classroom, NCERT initiated a programme in 1957. Under this scheme academic and financial assistance was given to the teachers for conducting experiments. The objectives of this scheme are as follows:

(i) To encourage teachers and schools to undertake projects directed towards the improvement of classroom practices and related activities and also to encourage them to adopt scientific approach to the solution of their problems.

(ii) To encourage institutionalization of useful and successfully tried out educational practices.

\section{Microteaching}

As already referred to micro-teaching is another technique employed by teacher-educators for improving the skill of classroom teaching. It is an innovation which has recently been adopted both in Europe and India. Microteaching is meant to modify teacher's behavior particularly when he feels that he is deviating from teaching. Some work in this area 
has been done by a small team from the Department of Teacher Education in NCERT and Department of Education.( singh, 49).

\section{UGC Panel on Teacher Education}

The University Grants Commission has a panel on teacher education. The UGC's concern for teacher education is reflected in its creation of a Centre for Advanced Study in Education (CASE), Baroda. Indeed, as far as UGC is concerned the CASE is supposed to spearhead the movement for reform in education. So far it does not appear that CASE has shown any inclination. Their effort has largely been noticeable in registering candidates for Ph.D. in education.

\section{A Glimpse into Future}

As a result of recommendations made by different panels of NCTE one could make surmises about the shape of things to come. The State Board of Teacher Education, it is hoped, would start playing a major role both for purposes of standardizing teacher education and also determining the level of grants each level of teacher education should get. Prof Desgupta writes:

If the destiny of India is being shaped in the class rooms then teachers have to play a vital role in inspiring and moulding the personal and national character of the educates. (224). 


\section{Bibliography}

Dasgupta, Seuti. Agenda for Education: Design and Direction. New Delhi: Kanishka Pub, 2018

Srivastava, Anil. Acquiring Excellence at College:A tutorial Handbook. New Delhi: The Learning Lab, 1933

Edelfelt, Roy. Teachers for the New Millenium. California: Corwin Press, INC, 1996.

Singh, R.P. Studies in Teacher Education-An overview. New Delhi: Bahri publication, 1980

Sharma, Shashi Prabha. Teacher Education: Principles, Theories and Practices. New Delhi: 2003. 